\title{
ENERGY CULTURES IN THE EUROPEAN UNION
}

The present text aims to analyse "energy cultures" in the European Union, and thus attempts to verify the assumption underlying the legitimacy of statements positing a division of the European Union member states according to particular kinds of energy consumption practice. In the first place one should point to two main directions of energy cultures analysis, which can be presented as follows: (1) a presentation of a culture in the form of the conversion of resources as well as the impact of the conversion on the natural environment, (2) an energy culture as a special sphere of social awareness. These two directions of thought are connected with the two main roots of research into culture itself: (1) culture as farming and animal husbandry (presently the domain of natural sciences), and (2) culture as a body of immaterial artefacts and a reproduction of social practice (presently the domain of social sciences and humanities) (Kłosowska, 1969; Kłosowska, 1972; Burszta, 1998: 35-57; Strinati, 1998: 15-49).

It should be stressed that in a great many cases - despite invoking "humanistic strategies in the attitude towards energy issues", that is to the approaches to the energy culture as a specific kind of public awareness - the analyses are frequently nothing but the issues concerned with data such as the GHG emission index, the energy intensity index, the quantitative data on primary energy production, etc. (Lucki, Misiak, 2010; Pach-Gurgul, 2012). Therefore, by emphasising the willingness to research energy cultures, it is quantitative data that are often analysed, and their results are extrapolated to public awareness and social practice, while no attempt is made at a broader analysis of awareness with the aid of qualitative techniques. This however does not mean that no research is conducted into awareness of - for instance - the practice adopted by energy consumers, citizens' attitude to particular energy sources, etc. Qualitative research of the "man-energy" kind abounds, but not all of it follows from the willingness to analyse the problem of energy culture. Frequently, the research is concerned with the analysis of environmental awareness, environment-friendly practice or attitudes to infrastructure investments, such as nuclear power plants or wind farms (Cf. Papuziński, 2006: 33-40; Tuszyńska, 2007: 233-236; Hłobił, 2010: 87-94).

Given the necessity to make the research problem more specific, the text addresses the following research questions: (1) Is the claim that the European Union presents special "energy cultures" legitimate?, (2) Did the decade of 2001-2011 witness changes in the field of the European Union "energy cultures", as earlier recognized by the literature? In order to see the research process through, the following working research hypotheses have been subjected to verification: (1) It must be posited that the dissimilarities in energy structures of particular EU member states are an outstanding premise on which to base a recognition of the existence of specific 'energy cultures' in the European Union, (2) It must be assumed that in the period of 2001-2011 there were 
changes in the area of 'energy cultures' of the European Union, which had earlier been recognised in the literature.

\section{THE CONCEPT AND EXAMPLES OF 'ENERGY CULTURES'}

Z. Łucki and W. Misiak define an energy culture as "a humanistic strategy in the approach to energy issues, both on the part of producers and consumers, which enables a resolution of social problems." Interestingly, they set out to analyse the term of an energy culture by referring to The Two Cultures, a well-known text on the history of science by C. P. Snow. Snow's text serves as a pretext for invoking the bipolar division of sciences on account of the methodological dimension into idiographic and nomological ones. The authors point out that their wish is to approach an energy culture as a field of research, through three prisms - the way Snow characterised scientific cultures - ("scientific", "humanistic", and "social"). For Z. Łucki and W. Misiak the following constitute component parts of an energy culture: (1) decarbonisation of human activity, (2) an improvement in the efficient use of energy carriers, (3) proper regard for energy displayed by consumers, (4) supplying the public with cheap and reliable energy (Snow, 2001; Łucki, Misiak, 2010: 47-49).

Both the authors point to two main sets of factors influencing an energy culture: (1) the economic one, and (2) the social one. The same factors are invoked by A. Pach-Gurgul, however she erroneously quotes - after J. L. Campbell - other factors influencing an energy culture, e.g. the impact of the global culture, political trends. The reference is erroneous in view of the fact that by no means does J. L. Campbell's text address the issues of an "energy culture", while it analyses various ways of making politics in general (Pach-Gurgul, 2012: 164; Campbell, 2002: 21-38). Obviously, this does not mean that the factors per se are not worth taking into account in the process of analysing the set of factors influencing an "energy culture".

In 2007 Tapio and his research team presented an analysis of the decarbonisation processes applied to the economies of the European Union member states (EU-15) in the years 1970-2000. This research is invoked in the analyses by Z. Eucki and W. Misiak, as well as A. Pach-Gurgul, who reconstruct the types of energy cultures. In order to analyse the changes, Tapio and his colleagues employed three metrics: (1) decarbonisation of the whole economy, (2) decarbonisation of energy production and transport, and (3) dematerialisation of the economy. For this purpose they performed a cluster analysis and generated six clusters: (1) Belgium, Germany and Great Britain (Mature North European Economies 1), (2) France and the Netherlands (Mature North European Economies 2), (3) Sweden and Finland (Mature North European Economies 3), (4) Austria, Italy and Spain (Central and South European Economies), (5) Greece and Portugal (Peripheral South European Economies), (6) Denmark, Ireland and Luxembourg (as outlying countries) (Tapio et. al., 2007: 433-451). Despite the six clusters being distinguished in the research of Tapio and his team, it is possible to point to two kinds of culture: the North European and the South European one. It is worth emphasising this fact on account of the research presented in this text. In their book Z. Eucki and W. Misiak perform a synthesis of publications dedicated to "energy cul- 
tures", distinguishing nine cultures: (1) the Anglo-Saxon one, (2) the French one, (3) the Scandinavian one, (4) the Mediterranean one, (5) the East European one, (6) the Latin American one, (7) the Japanese one, (8) the Chinese one, and (9) the primitive one (Eucki, Misiak, 2010: 75-76). For instance, the "energy culture of the French type" is to be characterised by the predominance of nuclear power, a minimum supply of coal, a low emission and energy intensity of the economy, while the "energy culture of the Scandinavian type" is to be characterised by a great significance of renewable energy sources, a low consumption of coal, low-emission and intensity indexes of the economy. It is to be noted that in their typology, Łucki and Misiak included a description of energy markets, that is an attitude of individual states to sector liberalisation, which has been at length addressed in A. Midttun's publications (Midttun, 2001; Finon, Midttun, 2004).

\section{METHODOLOGY}

The text sets out to verify the results of the research into the existence of "energy cultures" in the European Union, which have been presented by the following persons: (1) A. Pach-Gurgul, (2) Z. Łucki and W. Misiak (3) P. Tapio, D. Banister, J. Luukkanen, J. Vehma and R. Willamo. As regards A. Pach-Gurgul, and P. Tapio and his research team, a statistical analysis was carried out on the basis of the following research tools employed for the purpose of the cluster analysis: Ward's method, complete linkage, k-means, multidimensional scaling. A comparative analysis of the research processes authored by the above-mentioned researchers is difficult because of: (1) a selection of various statistical instruments (e.g. for the purpose of cluster analysis A. Pach-Gurgul uses Ward's method, the complete linkage algorithm, the $k$-means method and multidimensional scaling, whereas P. Tapio and his research team use the complete linkage algorithm, and Z. Lucki and W. Misiak do not conduct a statistical analysis at all, limiting themselves only to a synthesis and referring to other scientists' research), (2) a selection of various indexes characterising potential and distinguished "energy cultures" (Tapio et. al., 2007: 433-451; Łucki, Misiak, 2010: 43-91; Pach-Gurgul, 2012: 159-177).

The object of the present text is not to discuss research tools or to establish which one of the statistical methods is more effective - the complete linkage algorithm or perhaps other methods of cluster analysis. Such problems are usually analysed along with a presentation of various statistical methods (Cf. Aldenderfer, Blashfield, 1984; Kaufman, Rousseeuw, 2005; Stanisz, 2007; Everitt, Landau, Leese, Stahl, 2011; Mirkin, 2015). The same attitude was adopted in relation to the differences in the selection of indexes characterising "energy cultures". It is noteworthy that the reasons for using particular indexes concerned with the use of energy may be, for instance, pragmatics-motivated (an access to data) or teleology-motivated (related to the objective that has been set in a research process).

However, it must be pointed out that on account of the willingness to conduct a comparative analysis, following A. Pach-Gurgul, only a selection of statistical methods have been adopted for the purpose of the research, to wit: (1) Ward's method (the minimum variance method), (2) the $k$-means method (Pach-Gurgul, 2012: 159-177). The same applied to the indexes used for the purpose of classification of the clusters, which in turn could be related to particular "energy cultures". The problem of similarities and dissimilarities in this scope will be discussed in the subsequent point of the text. 
Also, it must be emphasised that in their analyses, both P. Tapio and his research team, and A. Pach-Gurgul subjected a different number of states to analysis, and adopted different timeframes. As for P. Tapio and his research team, 15 member states of the so-called "old" European Union (EU-15) were analysed within the period of 1970-2000; A. Pach-Gurgul's analysis covered 27 European Union member states (EU-27) and the focus was 2008. In the present text the subjective scope of the analysis covers 28 European Union member states (EU-28) and the indexes of 2011. Furthermore, for comparative purposes the same kind of analysis of 2001 is employed. Noteworthily, the text does not include detailed calculations in this respect.

Some light should be shed on the methods used to verify the hypotheses and the comparative analysis. As mentioned before, the research used clustering, which is a common method for analysing empirical data. The method serves to group objects and variables in indefinite groups.

In the first place - following A. Pach-Gurgul - the use was made of Ward's method, which is one of the most frequently employed agglomerative clustering method. The characteristic feature of this method is the use of a variance analysis for the purpose of determining the distance between clusters. The distance between one cluster composed of objects and another one cannot be directly expressed by way of the distance between the objects belonging to these clusters (Kaufman, Rousseeuw, 2005: 230-234; Stanisz, 2007: 122; Mirkin, 2015: 111-136). Hence, "the method aims to minimise the sum of squared deviations of any two clusters which can be formed at any stage" (Analiza skupien, 2015). Therefore, clusters that "ensure the minimum sum of squared distances from the centre of mass of a new cluster, which they create" are merged (Roszko-Wojtowicz, 2014: 74). The literature points out that this kind of agglomerative method is cognitively effective, however it yields small, and yet most natural clusters (Roszko-Wójtowicz, 2014: 74; Analiza skupień, 2015).

Another method employed is the method of $k$-means (i.e. a non-hierarchical algorithm of cluster analysis). This clustering method is in its design different from agglomerative and divisive methods (including Ward's method). Hierarchical methods generate arranged cluster trees, whereby lower-order clusters are subsumed under higher-order ones; the $k$-means method divides clusters in such a manner that no cluster is a sub-cluster of another cluster (Stanisz, 2007: 127-128). The choice of a specified number of clusters results in groups of objects that are most similar (close), whereas objects from other groups are most different (distant). Noteworthily, it must be pointed out that it is the analysing person who makes an arbitrary choice as to the number of groups made up of particular objects (Sokołowski, 2002; Mirkin, 2015: 75-110).

\section{INDEXES OF 'ENERGY CULTURES'}

\section{A selection of indexes}

The introduction contains assumptions to be verified, that is the assumptions of the existence or non-existence of special "energy cultures", as well as the assumptions of changes occurring in the energy cultures earlier recognised in the literature. A selection 
of indexes characterising an "energy culture" is essential for this purpose. Arguably, the very choice of indexes is a definiens of sorts of the term in question. The text refers to indexes chosen by Pach-Gurgul, but given the lack of vital data concerned with the manner of calculating some indexes, the text does not undertake an appropriate comparative analysis. The above-mentioned author employed the following indexes for the purpose of the analysis of the EU-27 "energy culture": (1) an index of energy intensity (kgoe/€1000), (2) an index of energy consumption per capita (toe/cap), (3) an index of GHG emission per capita ( $\mathrm{t} \mathrm{CO}$ equiv.), (4) a level of primary energy production by fuel kinds in Mtoe (coal, petroleum, gas, nuclear fuel, renewable energy sources) (Pach-Gurgul, 2012: 165-177).

In the text, given the difficulty of characterising "energy cultures" of the European Union member states, the following indexes have been adopted: (1) the energy intensity of an economy (kgoe/€1000), (2) energy consumption per capita (toe/cap), (3) the emission of greenhouse gases per capita ( $\mathrm{t} \mathrm{CO}_{2}$ equiv.), (4) a level of gross inland energy consumption in Mtoe (for solid fuels, petroleum and petroleum products, gas, nuclear fuel, renewable energy sources, non-renewable energy sources). The selection of indexes shows a visible difference in that the index of primary energy production has been replaced with the index of gross inland energy consumption with a different fuel structure (Tab. 1).

Table 1

Indexes of energy cultures in the European Union member states in 2011 (EU-28)

\begin{tabular}{|c|c|c|c|c|c|c|c|c|c|}
\hline \multirow{3}{*}{$\sum_{\infty}^{\infty}$} & \multirow[b]{2}{*}{$\begin{array}{c}\text { Energy } \\
\text { intensity } \\
\text { of the } \\
\text { economy }\end{array}$} & \multirow{2}{*}{$\begin{array}{l}\text { Gross in- } \\
\text { land con- } \\
\text { sumption } \\
\text { of energy } \\
\text { per capita }\end{array}$} & \multirow{2}{*}{$\begin{array}{l}\text { Green- } \\
\text { house } \\
\text { gas emis- } \\
\text { sions per } \\
\text { capita }\end{array}$} & \multicolumn{6}{|c|}{ Gross inland energy consumption } \\
\hline & & & & $\begin{array}{l}\text { Solid } \\
\text { fuels }\end{array}$ & $\begin{array}{c}\text { Petro- } \\
\text { leum } \\
\text { and } p . \\
\text { products }\end{array}$ & Gas & $\begin{array}{l}\text { Nucle- } \\
\text { ar fuel }\end{array}$ & RES & $\begin{array}{l}\text { non- } \\
\text { RES }\end{array}$ \\
\hline & $\begin{array}{c}\text { (kgoe } \\
/ \in 1000)\end{array}$ & (toe/cap) & $\begin{array}{l}\left(\mathrm{t} \mathrm{CO}_{2}\right. \\
\text { equiv. })\end{array}$ & (Mtoe) & (Mtoe) & (Mtoe) & (Mtoe) & (Mtoe) & (Mtoe) \\
\hline & [1] & {$[2]$} & [3] & [4] & {$[5]$} & {$[6]$} & {$[7]$} & {$[8]$} & [9] \\
\hline $\mathrm{BE}$ & 182.1 & 5.43 & 13.43295 & 3.4 & 22.9 & 15.1 & 12.4 & 2.9 & 2.7 \\
\hline BG & 705.5 & 2.62 & 7.41016 & 8.1 & 3.7 & 2.6 & 4.2 & 1.4 & 0.0 \\
\hline $\mathrm{CZ}$ & 355.4 & 4.13 & 9.25921 & 18.4 & 9.0 & 6.8 & 7.3 & 3.2 & 0.2 \\
\hline DK & 89.7 & 3.42 & 8.19344 & 2.5 & 7.1 & 3.5 & 0.0 & 4.2 & 0.4 \\
\hline $\mathrm{DE}$ & 129.2 & 3.87 & 9.62759 & 80.4 & 108.3 & 69.6 & 27.9 & 29.7 & 3.9 \\
\hline $\mathrm{EE}$ & 505.8 & 4.60 & 4.31386 & 4.1 & 1.1 & 0.5 & 0.0 & 0.8 & 0.0 \\
\hline $\mathrm{IE}$ & 83.7 & 3.03 & 7.75152 & 2.0 & 7.0 & 4.1 & 0.0 & 0.8 & 0.0 \\
\hline $\mathrm{EL}$ & 154.4 & 2.47 & 8.55788 & 7.9 & 13.5 & 4.0 & 0.0 & 2.1 & 0.0 \\
\hline ES & 135.1 & 2.79 & 6.80640 & 12.3 & 57.7 & 28.9 & 14.9 & 14.7 & 0.2 \\
\hline $\mathrm{FR}$ & 142.6 & 3.99 & 5.73271 & 10.2 & 82.0 & 37.0 & 114.1 & 18.1 & 1.2 \\
\hline HR & 231.9 & 1.94 & 3.97683 & 0.7 & 3.7 & 2.6 & 0.0 & 0.9 & 0.0 \\
\hline IT & 120.7 & 2.85 & 6.74506 & 15.9 & 67.3 & 63.8 & 0.0 & 20.0 & 1.1 \\
\hline $\mathrm{CY}$ & 174.0 & 3.18 & 7.79205 & 0.0 & 2.6 & 0.0 & 0.0 & 0.1 & 0.0 \\
\hline LV & 333.5 & 2.05 & 3.65131 & 0.1 & 1.4 & 1.3 & 0.0 & 1.4 & 0.1 \\
\hline
\end{tabular}




\begin{tabular}{|l|c|c|r|r|r|r|r|r|r||}
\hline & {$[1]$} & {$[2]$} & {$[3]$} & {$[4]$} & {$[5]$} & {$[6]$} & {$[7]$} & {$[8]$} & {$[9]$} \\
\hline LT & 298.7 & 2.32 & 4.29685 & 0.2 & 2.4 & 2.7 & 0.0 & 1.1 & 0.0 \\
\hline LU & 136.7 & 8.96 & 23.10506 & 0.1 & 2.9 & 1.0 & 0.0 & 0.1 & 0.0 \\
\hline HU & 281.6 & 2.53 & 5.22968 & 2.8 & 6.4 & 9.4 & 4.1 & 1.9 & 0.1 \\
\hline MT & 163.5 & 2.71 & 18.41715 & 0.0 & 0.9 & 0.0 & 0.0 & 0.0 & 0.0 \\
\hline NL & 144.7 & 4.88 & 14.39552 & 7.5 & 32.5 & 34.3 & 1.1 & 3.3 & 0.8 \\
\hline AT & 125.0 & 4.04 & 8.43828 & 3.5 & 12.1 & 7.8 & 0.0 & 8.8 & 0.7 \\
\hline PL & 314.7 & 2.65 & 8.01486 & 54.6 & 25.7 & 12.8 & 0.0 & 8.0 & 0.6 \\
\hline PT & 150.8 & 2.26 & 4.94078 & 2.2 & 11.4 & 4.5 & 0.0 & 5.1 & 0.2 \\
\hline RO & 393.7 & 1.70 & 4.08505 & 8.2 & 9.3 & 11.1 & 3.0 & 5.1 & 0.0 \\
\hline SI & 230.6 & 3.54 & 7.99669 & 1.5 & 2.6 & 0.7 & 1.6 & 1.0 & 0.0 \\
\hline SK & 349.3 & 3.23 & 6.39849 & 3.7 & 3.6 & 4.6 & 4.0 & 1.3 & 0.0 \\
\hline FI & 210.4 & 6.65 & 9.81307 & 5.7 & 10.0 & 3.4 & 6.0 & 9.1 & 0.2 \\
\hline SE & 149.4 & 5.26 & 5.94618 & 2.5 & 14.0 & 1.2 & 15.6 & 16.5 & 0.5 \\
\hline UK & 102.8 & 3.18 & 7.78824 & 30.6 & 69.7 & 70.2 & 17.8 & 7.7 & 0.7 \\
\hline
\end{tabular}

Source: Author's own study based on Eurostat, IEA data.

\section{A description of indexes}

The first index is energy intensity, which is concerned with the operation of an economy. It defines energy consumption in production processes in particular sectors of economy. The differences in the level of energy intensity may be indicative of the level of economic development, an economic structure, a technological advancement, the type of carriers used in the primary energy production. A low level of energy intensity points to a higher efficiency of energy sources management. It must however be pointed out that a low energy intensity may characterise economically underdeveloped countries, with the provision that we are dealing with a low energy consumption in general. As regards energy intensity, there is a variety of indexes to choose from: (1) an index of GDP energy intensity (calculated as the ratio of the amount of energy consumed to the value of GDP), (2) an index of energy consumption per capita (calculated as the ratio of primary energy consumed to the population) (Pach-Gurgul, 2012: 166-167; Energy glossary, 2015).

Another index is the greenhouse gas emission calculated as the ratio of the emission to the population (Greenhouse gas emission statistics, 2015). Emissions may be suggestive of an energy structure of particular countries, a technological advancement and the level of clean energy sources development. Taking into account emissions of very small countries, such as Luxembourg, may become problematic for analyses. The tendency which should be included in the emission analyses presupposes a correlation between a GDP growth and an emission increase. The index level may also be affected by the dominance of particular carriers in the energy production structure.

The last index to characterise an "energy culture" is the gross inland energy consumption expressed in Mtoe. Unlike the selection of indexes made by A. Pach-Gurgul, the text does not employ the index based on primary energy production by the type of fuel. The index of gross inland energy consumption takes into account the total energy demand in a given country, and as such it defines the amount of energy required to meet the con- 
sumption needs. This kind of consumption embraces: (1) energy consumption by the energy industry, (2) losses sustained in relation to distribution and processing, (3) the ultimate energy consumption by end users (Eurostat statistics explained, 2015). The elements taken into account while calculating the index of gross inland energy consumption are: (1) primary production, (2) the so-called reclaimed products, (3) net energy imports, (4) changes in stores (however, not including the so-called energy/oil stored in international sea bunkers) (Energy glossary, 2015; Eurostat statistics explained, 2015).

\section{AN ATTEMPT AT GROUPING THE EUROPEAN UNION STATES}

\section{Ward's method}

Ward's method was employed to group the European Union member states (EU-28) in 2011, which made it possible to distinguish four existing clusters: (1) Belgium, the Netherlands, Austria, Sweden, Finland and Luxembourg (however Luxembourg stands out against the other countries); (2) Bulgaria, the Czech Republic, Estonia, Poland, Croatia, Latvia, Lithuania, Hungary, Slovakia and Romania (a clear division of these countries into the former four and the latter six is observable); (3) Denmark, Ireland, Greece, Portugal, Cyprus, Slovenia and Malta (however Malta stands out against the other countries); (4) Germany, Spain, Italy, Great Britain and France, however Germany stands out against the other countries (Diag. 1).

Diagram 1. A dendrogram (Ward's method with Euclidean distance)

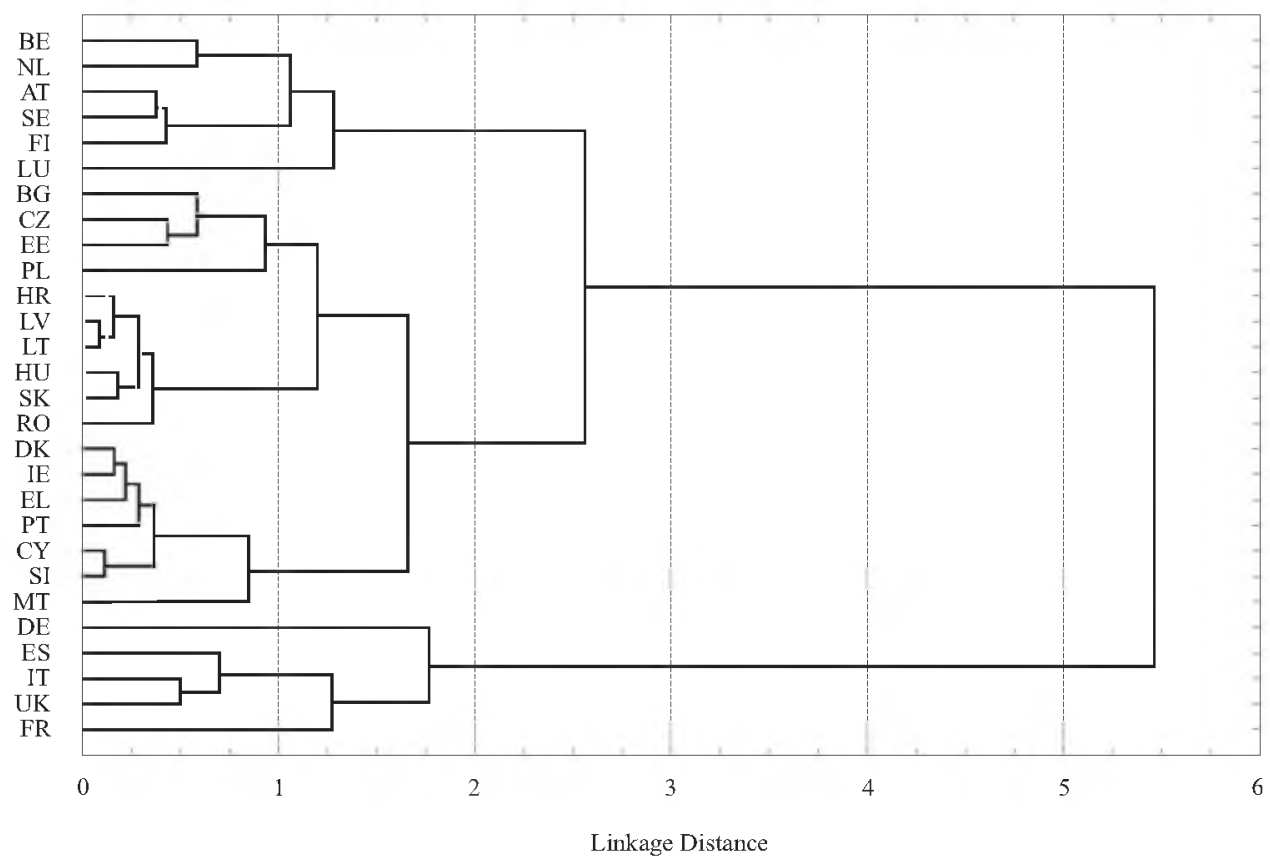

Source: Author's own study. 


\section{The $k$-means method}

With the optimal number of clusters established, the text sets out to find out what areas characterising an "energy culture" display the biggest differences between the distinguished groups (Tab. 2). Thanks to the $k$-means method it is possible to conclude that the differences between distinguished clusters are highly significant $(p<0.01)$ in respect of almost all the analysed variables, with the exception of nuclear fuels, where the differences are significant with the significance level of 0.05 (Tab. 3).

Table 2

The mean values of the analysed indexes in individual clusters ( $k$-means method)

\begin{tabular}{|l|c|c|c|c|c|c||}
\hline \multicolumn{1}{|c|}{ Individual indexes: } & \multicolumn{5}{c|}{ Cluster } \\
\hline & 1 & 2 & 3 & 4 & 5 & 6 \\
\hline Energy intensity of the economy & 0.0669 & 0.6218 & 0.1121 & 0.3340 & 0.0732 & 0.1139 \\
\hline $\begin{array}{l}\text { Gross inland consumption of energy } \\
\text { per capita }\end{array}$ & 0.2070 & 0.2479 & 0.2908 & 0.0813 & 0.2989 & 0.6506 \\
\hline Greenhouse gas emissions per capita & 0.1602 & 0.1850 & 0.2858 & 0.0516 & 0.3072 & 0.6850 \\
\hline Solid fuels & 0.2146 & 0.2649 & 0.0354 & 0.0318 & 1.0000 & 0.0456 \\
\hline Petroleum and petroleum products & 0.6357 & 0.0836 & 0.0638 & 0.0424 & 1.0000 & 0.1726 \\
\hline Gas & 0.7119 & 0.0808 & 0.0391 & 0.0737 & 0.9915 & 0.2393 \\
\hline Nuclear fuel & 0.3216 & 0.0252 & 0.0226 & 0.0139 & 0.2445 & 0.0394 \\
\hline RES & 0.5093 & 0.1128 & 0.1594 & 0.0808 & 1.0000 & 0.0707 \\
\hline non-RES & 0.2051 & 0.0513 & 0.0513 & 0.0147 & 1.0000 & 0.2991 \\
\hline
\end{tabular}

Source: Author's own study.

Cluster variations - variance analysis results (ANOVA)

Table 3

\begin{tabular}{||l|c|c|c|c|c|c||}
\hline \multirow{2}{*}{\multicolumn{1}{|c|}{ Individual indexes: }} & \multicolumn{7}{c|}{ ANOVA } \\
\cline { 2 - 8 } & $\begin{array}{c}\text { Between } \\
\text { groups } \\
\text { variance }\end{array}$ & df & $\begin{array}{c}\text { Within } \\
\text { groups } \\
\text { variance }\end{array}$ & df & F Test & P Value \\
\hline Energy intensity of the economy & 0.99 & 5 & 0.40 & 22 & $\mathbf{1 0 . 8 5}$ & $<\mathbf{0 . 0 0 0 1}$ \\
\hline $\begin{array}{l}\text { Gross inland consumption of energy } \\
\text { per capita }\end{array}$ & 0.70 & 5 & 0.56 & 22 & $\mathbf{5 . 4 8}$ & $\mathbf{0 . 0 0 2 0}$ \\
\hline Greenhouse gas emissions per capita & 0.90 & 5 & 0.48 & 22 & $\mathbf{8 . 3 1}$ & $\mathbf{0 . 0 0 0 2}$ \\
\hline Solid fuels & 1.03 & 5 & 0.30 & 22 & $\mathbf{1 4 . 8 3}$ & $<\mathbf{0 . 0 0 0 1}$ \\
\hline Petroleum and petroleum products & 1.79 & 5 & 0.12 & 22 & $\mathbf{6 4 . 8 6}$ & $<\mathbf{0 . 0 0 0 1}$ \\
\hline Gas & 2.08 & 5 & 0.40 & 22 & $\mathbf{2 2 . 6 3}$ & $<\mathbf{0 . 0 0 0 1}$ \\
\hline Nuclear fuel & 0.34 & 5 & 0.66 & 22 & $\mathbf{2 . 2 6}$ & $\mathbf{0 . 0 8 4 6}$ \\
\hline RES & 1.22 & 5 & 0.46 & 22 & $\mathbf{1 1 . 7 7}$ & $<\mathbf{0 . 0 0 0 1}$ \\
\hline non -RES & 1.04 & 5 & 0.35 & 22 & $\mathbf{1 3 . 0 5}$ & $<\mathbf{0 . 0 0 0 1}$ \\
\hline
\end{tabular}

Source: Author's own study. 
An extension of Table 2 is Diagram 2, which graphically presents mean levels of analysed features for the distinguished clusters. The first cluster includes Spain, France, Italy and Great Britain (which is motivated by relatively high scales of gross energy consumption). The second cluster includes Bulgaria, the Czech Republic, Estonia and Poland (the characteristic feature here is the highest level of energy intensity - kgoe/ $€ 1000$ ). The third cluster includes Denmark, Ireland, Greece, Cyprus, Malta, Austria, Slovenia, Finland and Sweden. This group is characterised by low results in all the scales, the highest ones concerning the index of energy consumption per capita (toe/cap) as well as the index of $\mathrm{GHG}$ emission per capita in relation to energy consumption ( $\left.\mathrm{COO}_{2}\right)$. The fourth cluster includes Croatia, Latvia, Lithuania, Hungary, Portugal, Romania and Slovakia. This group of countries is characterised by the lowest results in all the scales, except for energy intensity (kgoe/€1000). The fifth cluster embraces only Germany, characterised by high scales of gross inland energy consumption. The last, sixth cluster contains the following countries: Belgium, Luxembourg and the Netherlands. This group is characterised by the highest indexes of energy consumption per capita (toe/capita), as well as the index of GHG emission per capita in relation to energy consumption ( $\mathrm{C}_{2}$ ).

Diagram 2. Means of particular clusters ( $k$-means method)

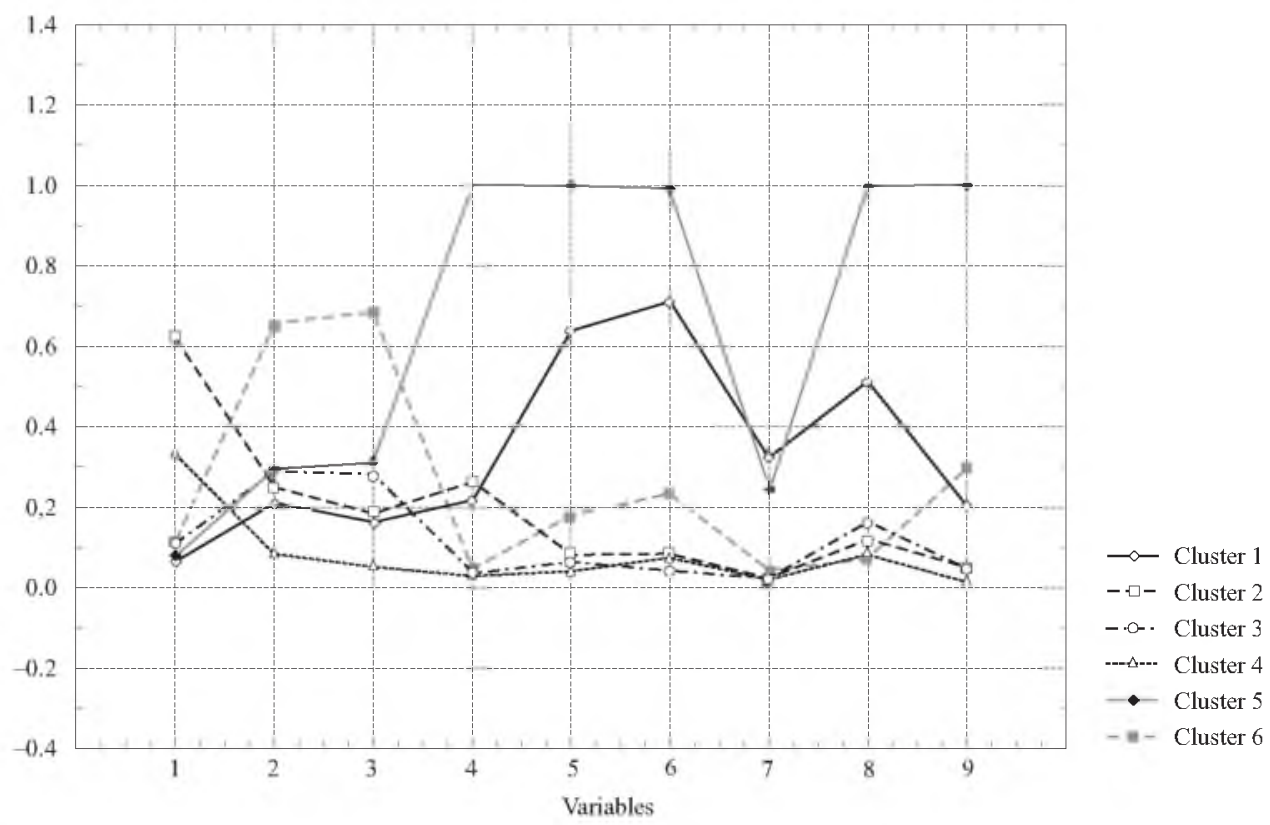

Individual indexes: [1] Energy intensity of the economy, [2] Gross inland consumption of energy per capita, [3] Greenhouse gas emission per capita, [4] Solid fuels, [5] Petroleum and petroleum products, [6] Gas, [7] Nuclear fuel, [8] RES, [9] non-RES.

Source: Author's own study.

The main object of the analysis presented in the text was to point to and confirm the existence of special "energy cultures" in the European Union. In order to achieve this 
aim the use was made of research present in the literature, inter alia, in the publications containing statistical analyses by: (1) A. Pach-Gurgul, (2) P. Tapio and his research team - Banister, J. Luukkanen, J. Vehma i R. Willamo, also in a review, (3) Z. Łucki and $\mathrm{W}$. Misiak. Compared with the invoked research, the timeframe of the analysis in the text covered 2011, and the subjective scope embraced 28 countries (EU-28).

As part of the research process the following research hypotheses were subjected to verification: (1) It must be assumed that the dissimilarities in energy structures of particular EU member states are an outstanding premise on which to base a recognition of the existence of specific "energy cultures" in the European Union, (2) It must be assumed that in the period of 2001-2011 there occurred changes in the area of "energy cultures" of the European Union, which had earlier been recognised in the literature. In this scope the following conclusions ought to be presented:

I. CONCLUSIONS: The differences in energy structures result in the possibility of pointing to particular features characterising member states and clusters of countries, partially because of the predominance of specific energy carriers and/or a way of their conversion. On account of the use of selected indexes for the purpose of characterising the specificity of the European Union member states, six clusters have been distinguished, and they include the following countries: (1) Spain, France, Italy and Great Britain; (2) Bulgaria, the Czech Republic, Estonia and Poland; (3) Denmark, Ireland, Greece, Cyprus, Malta, Austria, Slovenia, Finland and Sweden; (4) Croatia, Latvia, Lithuania, Hungary, Portugal, Romania and Slovakia; (5) Germany; (6) Belgium, Luxembourg and the Netherlands.

An observable cluster that recurs in the research by A. Pach-Gurgul as well as in the analysis presented in the text covering 2011, embraces Bulgaria, the Czech Republic, Estonia and Poland (Cluster II). As for Ward's method the cluster is broader, but features an outstanding group of the above-mentioned countries (also including: Croatia, Latvia, Lithuania, Hungary, Slovakia and Romania). Besides, in this model, in comparison with A. Pach-Gurgul's research, another cluster is by and large repeated, including Croatia, Latvia, Lithuania, Hungary, Portugal, Romania and Slovakia - Cluster IV (for a variety of reasons Croatia and Portugal are not repeated). The characteristic feature of both clusters is a higher scale of the index of energy intensity (kgoe/ $/ 1000$ ). This shows that it is legitimate to recognise the existence of the division of the European Union into the two "energy cultures": the Western European one and Eastern European one. The main factor behind this division is the energy intensity of the economies of individual member states. Unlike the analysis by P. Tapio and his research team, the axis of division has changed considerably, for within the so-called "old" European Union (EU-15) there was an observable general division into the Northern European and Southern European 'energy cultures'.

Both the above-mentioned clusters (II and IV) can be associated with the "Eastern European culture" as part of the division presented by Z. Łucki and W. Misiak. The energy culture distinguished by the two researchers is to be characterised by: (1) a variety of energy policies, (2) a high energy intensity of the economy, (3) a low electric energy consumption, (4) limited awareness, (5) a negative attitude towards energy market liberalisation. In the case of Bulgaria, the Czech Republic and Poland (Cluster II), the characteristic feature is a considerable share of solid fuels in the energy mix of the gross 
inland energy consumption. The countries included in Cluster IV are characterised by a smaller share of solid fuels and a higher diversity of energy structure.

As part of the $k$-means clustering method, it is worth pointing out two clusters of countries: Cluster I (Spain, France, Italy, Great Britain) and Cluster V (Germany). The countries in both clusters belong to the so-called "old" European Union, and their main feature is a substantial level of energy production, Germany being the largest producer. In both cases, the characteristic features are a marked share of renewable energy sources, gas as well as petroleum and petroleum products in the gross inland energy consumption. Furthermore, both clusters are characterised by a low or relatively low index of energy intensity (kgoe/ $€ 1000)$.

As part of the clustering based on the $k$-means method, in both periods, that is in 2001 and 2011 the cluster comprising Belgium, Luxembourg and the Netherlands was repeated. This cluster is characterised by a high index of energy consumption per capita and a high index of GHG emission per capita.

II. CONCLUSIONS: It must be emphasised that the period 2001-2010 is connected with the transition process of the electric energy and gas sectors in the European Union. The process is also associated with the introduction of the $1^{\text {st }}$ Climate-Energy Package in the European Union. What is more, the changes will be continued on account of the efforts at building an Energy Union as well as the implementation of the so-called $2^{\text {nd }}$ Climate-Energy Package. Of particular significance is also the increase in the import dependence of the European Union, given the declining reserves of energy resources. Moreover, the objectives of the "green energy policy" will be giving rise to the increasing energy efficiency and the growing share of renewable energy sources in energy production, which may constitute a factor limiting the import dependence. Thus, it should be posited that in the long term we will be witnessing a homogenisation of indexes, e.g. the index of energy intensity.

These processes may result in the tendency for changes towards the model of the 'energy culture', which Z. Łucki and W. Misiak have termed a "Scandinavian culture", that is one characterised by the following features: (1) a development of RES, (2) a low consumption of coal, (3) a low index of GHG emission, (4) a considerable energy consumption, (5) a low energy intensity, (6) a heightened environment- and energy-consciousness.

By way of comparing the analyses for 2011 and for 2001, based on the $k$-means clustering method, it must be stressed that Belgium, Luxembourg and the Netherlands hold steady in the cluster (Cluster VI), whereby they abide by the roles played by the features earlier ascribed to them. A measure of stability can also be observed in the case of Spain, France, Italy, Great Britain and Germany (Clusters I and V). Noteworthily, Sweden has been eliminated from the group (despite lowering the scale of the first three indexes).

The distinctive feature of Eastern European countries is the high scale of the energy intensity index, as viewed against the backdrop of Clusters I and IV. Yet, some tendency towards stirring of the scale of energy intensity index is to be observed in this scope. A transformation of the energy structure will also prove quite a challenge here. Poland can serve as an example, whereby coal will continue to be the country's main electric energy carrier for the next 30 years. 
The comparative analysis featuring in the text is limited, and so it does not address all the issues concerned with the correlations between the presented 'energy cultures'. The work sets out to verify the results of the research into the existence of 'energy cultures' in the European Union, as presented by A. Pach-Gurgul, Z. Łucki and W. Misiak as well as P. Tapio and his research team. Still, the greatest emphasis has been laid on the proposals made by A. Pach-Gurgul, for it was her publication as well as the selection of indexes and research tools included therein that proved to be an inspiration for the present text. It should also be noted that the object of analysis in the text does not embrace a discussion of the legitimacy of employing specific methods for clustering.

\section{BIBLIOGRAPHY}

Aldenderfer M. S., Blashfield R. K. (1984), Cluster Analysis, Newbury Park-London-New Delhi. Analiza skupień (2015), http://www.statsoft.pl/textbook/stathome_stat.html?http\%3A\%2F\%2Fwww.statsoft.pl $\% 2$ Ftextbook $\% 2$ Fstcluan.html (01.07.2015).

Burszta W. J. (1998), Antropologia kultury, Poznań.

Campbell J. L. (2002), Ideas, Politics, and Public Policy, “Annual Review of Sociology”, Vol. 28.

Energy glossary, http://ec.europa.eu/eurostat/statistics-explained/index.php/Category:Energy_glossary (01.07.2015).

Eurostat statistics explained, http://ec.europa.eu/eurostat/statistics-explained/index.php/Mam_Page (01.07.2015).

Everitt B. S., Landau S., Leese M., Stahl D. (2011), Cluster Analysis, London.

Finon D., Midttun A. (ed.) (2004), Reshaping European Gas and Electricity Industries Regulation, Markets and Business Strategies, London, New York.

Greenhouse gas emission statistics, http://ec.europa.eu/eurostat/statistics-explained/index.php/ Greenhouse_gas_emission_statistics (02.07.2015).

Hłobił A. (2010), Teoria i praktyka edukacji ekologicznej na rzecz zrównoważonego rozwoju, "Problemy Ekorozwoju", No. 2, Vol. 5.

Kaufman L., Rousseeuw P. J. (2005), Finding Groups in Data An Introduction to Cluster Analysis, New Jersey.

Kłosowska A. (1969), Z historii i socjologii kultury, Warszawa.

Kłosowska A. (1972), Spoteczne ramy kultury, Warszawa.

Łucki Z., Misiak W. (2012), Energetyka a spoteczeństwo. Aspekty socjologiczne, Warszawa.

Midttun A. (2001), Perspectives on Commercial Positioning in the Deregulated European Electricity Markets, in: European Energy Industry Business Strategies, (ed.) A. Midttun, London-New York.

Midttun A. (ed.) (2001), European Energy Industry Business Strategies, London-New York.

Mirkin B. (2005), Clustering for Data Mining A Data Recovery Approach, Boca Raton-London-New York-Singapore.

Pach-Gurgul A. (2012), Jednolity rynek energii elektrycznej w Unii Europejskiej w kontekście bezpieczeństwa energetycznego Polski, Warszawa.

Papuziński A. (2006), Świadomość ekologiczna w świetle teorii i praktyki. Zarys politologicznego modelu świadomości ekologicznej, "Problemy Ekorozwoju", No. 1, Vol. 1. 
Roszko-Wójtowicz E. (2014), Analiza skupień w ocenie warunków pracy w krajach Unii Europejskiej, "Wiadomości Statystyczne", No. 11.

Snow Ch. P. (2001), The Two Cultures, London.

Sokolowski A. (2002), Metody stosowane $w$ data mining, http://www.statsoft.pl/Portals/0/Downloads/Metody_stosowane_w_data_mining.pdf (30.07.2015).

Stanisz A. (2007), Przystepny kurs statystyki z zastosowaniem STATISTICA PL na przykladach $z$ medycyny, t. 3: Analizy wielowymiarowe, Kraków.

Strinati D. (1998), Wprowadzenie do kultury popularnej, Poznań.

Tapio P., Banister D., Luukkanen J., Vehmas J., Willamo R. (2007), Energy and transport in comparison: Immaterialisation, dematerialisation and decarbonisation in the EU15 between 1970 and 2000, "Energy Policy", Vol. 35, Issue 1.

Tuszyńska L. (2007), Swiadomość środowiskowa spoleczeństwa polskiego "Problemy ekologii”, No. 5.

\begin{abstract}
The main objective of the text is to present an analysis that points to the existence of special "energy cultures" in the European Union. The comparative analysis encompassing the results of previous research into "energy cultures" employs statistical methods, i.e. a cluster analysis (Ward's clustering method and $k$-means clustering method). The main sections of the text address: (1) the concept and examples of "energy cultures", (2) a methodology of analysis, (3) a selection of indexes characterising "energy cultures", (4) an attempt at grouping the European Union member states with the aid of clustering, (5) conclusions. With a view to making the research problem more specific, the present text features the following questions: (1) Is the claim that the European Union manifests special 'energy cultures'legitimate?, (2) Did the decade of 2001-2011 witness changes in the field of the European Union 'energy cultures', as earlier recognised by the literature?
\end{abstract}

Key words: energy cultures, indexes of energy cultures, energy policy, European Union

\title{
KULTURY ENERGETYCZNE W UNII EUROPEJSKIE.J
}

\section{STRESZCZENIE}

Głównym celem tekstu jest prezentacja analizy, która wskazuje na istnienie szczególnych "kultur energetycznych" w Unii Europejskiej. W analizie porównawczej z dotychczasowymi wynikami badań nad "kulturami energetycznymi" wykorzystano metody statystyczne, tj. analizę skupień (grupowanie metodą Warda i grupowanie metodą k-średnich). Główne części pracy dotyczą: (1) pojęcia i przykładów "kultur energetycznych", (2) metodologii analizy, (3) doboru wskaźników charakteryzujących "kultury energetyczne", (4) próby grupowania państw członkowskich Unii Europejskich za pomocą analizy skupień, (5) wniosków. W celu uszczegółowienia problemu badawczego w pracy przedstawiono następujące pytania: (1) Czy zasadne jest twierdzenie, ze w Unii Europejskiej mamy do czynienia ze specyficznymi kulturami energetycznymi'?, (2) Czy w okresie 2001-2011, następujq zmiany w obrębie, stwierdzonych wcześniej w literaturze tematu, 'kultur energetycznych' w Unii Europejskiej?

Slowa kluczowe: kultury energetyczne, wskaźniki kultur energetycznych, polityka energetyczna, Unia Europejska 